\title{
Crossing histories: Brazilian planners of São Paulo and their transnational references (1910-1930)
}

\author{
Histórias cruzadas: urbanistas paulistanos e suas referências \\ transnacionais (1910-1930)
}

Heliana Angotti-Salgueiro[a] (ㄱ), José Geraldo Simões Junior[a] ()

[a] Universidade Presbiteriana Mackenzie (UPM), São Paulo, SP, Brasil

How to cite: Angotti-Salgueiro, H., \& Simões Junior, J. G. (2020). Crossing histories: Brazilian planners of São Paulo and their transnational references (1910-1930). urbe. Revista Brasileira de Gestão Urbana, 12, e20190116. https://doi.org/10.1590/2175-3369.012.e20190116

\begin{abstract}
This paper examines how some pioneering planners in the Brazilian state of São Paulo, Victor Freire, Prestes Maia, Ulhoa Cintra, and Anhaia Mello disseminated and appropriated the dominant principles of international urbanism in the period 1910-1930. The education in city planning is directly associated with the repertoire of engineering courses and professional associations. In this environment, where public debates on urban issues were intense, it is worth noting the presence of English urbanist Barry Parker, who lived for two years in São Paulo, implementing innovative projects and debating with local planners. The access to urban planning manuals and reviews, and the presence of these Brazilian professionals in international seminars, led to the dissemination of the international ideals and some resulting essays on the way these ideals could be applied in many fields: urban regulations, projects in downtown areas, housing, sanitation, town extension plans, city management, zoning, among others. Contradictions among practices, actors and references are requesting a conceptual and methodological effort attentive to the historical dimension of the "circulation" of ideals or their limits of intelligibility and reception in other scales of time and place, such as the one proposed in this paper.
\end{abstract}

Keywords: Brazilian planners. International dissemination. City plan ideals.

\section{Resumo}

O artigo examina a difusão e apropriação dos princípios dominantes no ideário urbanístico internacional, entre anos 1910-1930, pelos urbanistas pioneiros em São Paulo, Brasil: Victor Freire, Prestes Maia, Ulhoa Cintra e Anhaia Mello. A formação acadêmica desses pioneiros está diretamente associada a repertório de cursos de engenharia e associações profissionais. Quando o debate público sobre questões urbanas se tornou intenso, é importante registrar a presença do urbanista inglês Barry Parker, que viveu por dois anos em São Paulo, implantando projetos inovadores e debatendo com planejadores locais. $O$ acesso a manuais e revistas técnicas, assim como a participação desses profissionais em seminários internacionais, levou à difusão desse ideário e seus consequentes ensaios de aplicação em diversos campos: regulamentação urbana, projetos em áreas centrais, habitação, 
saneamento, extensão urbana, planos urbanísticos e gestão. O estudo desses discursos, da apropriação do ideário e as contradições entre práticas, atores e referências exigem um esforço conceitual $e$ metodológico baseado em uma dimensão histórica da "circulação" de ideais ou seus limites de inteligibilidade e recepção em outras escalas de tempo e lugar, como a proposta neste artigo.

Palavras-chave: Urbanistas brasileiros. Difusão internacional. Ideário urbanístico.

\section{Introduction}

It is known that São Paulo is Latin America's largest metropolis. However, its rapid growth started less than a century ago and, if at the local level, the historiography of urban design has been developed over recent decades (Campos, 2002; Simões, 2004; Ficher, 2005; Arasawa, 2008; Leme, 2005) the international literature has recorded little about the men who theorized on and wrote about this city during its evolutionary process. Most of the city planners were engineers from the Polytechnic School of the University of São Paulo, and also professors, seldom involved in urban management issues. They were acquainted with several international city-planning proposals due to the dissemination of books and periodicals, and to the meetings that brought them together in the first decades of the twentieth century.

Although today a global perspective is a methodological consensus in several fields of knowledge, some particulars of the histories of these urban planners remain absent from the standard widespread bibliography. In this sense, even though everybody identifies well-known authors - professionals who practiced the discipline in European and North American countries, their theoretical essays, and their planning processes - there is still a vast field to study more deeply and investigate how South-American urban planners have appropriated this material ${ }^{1}$.

We all know that urban and architectural designs spread, their propagation and international character dates from previous centuries. However, this discussion will focus on the pioneers of the early twentieth-century in São Paulo, a period considered by historians to be the founding moment of city planning as a discipline. Methodologically speaking, we know that case studies and analyses of authors' trajectories (ideas and designs) that have appropriated references and models have been used as premises for historical studies since the 1980s. At that time, cultural transfers became important in the analyses, with attention to the possibilities of local contexts, or a specific understanding of the countries that were "importing" these ideas 2 .

Therefore, this paper presents aspects of the trajectories of the Brazilian city planners who worked in the urban environment of the city of São Paulo between 1910 and 1930, one of the most important periods of the history of Brazilian urban planning ${ }^{3}$. Some subjects of their publications, projects and interventions proposed for this metropolis in the process of full development will be generally discussed here. Crossing histories ${ }^{4}$ and intellectual references of some professionals, their role in the urbanization of the city debate and in founding the urban planning discipline, will certainly assist in bringing to light some new facets of the thinking of Latin America's pioneers.

\footnotetext{
${ }^{1}$ Among published works see Gomes (2009); Novick (2003); Almandoz (2002).

${ }^{2}$ This notion has been studied since the 1980s notably by Michael Werner and Michel Espagne - see a recent article by Espagne, "La notion de transfer culturel" (Espagne, 2013).

${ }^{3}$ See a synthesis by Pereira (2003). A turning point in the history of Brazilian city planning, dating back to the nineteenth century, is the foundation of Belo Horizonte, see Angotti-Salgueiro (1997), to be printed in Portuguese by Edusp.

${ }^{4}$ The expression crossing history comes from Werner \& Zimmermann (2004), but is also employed by others authors quoted by them. It refers to researches of intersections between countries, regions, people and regards. Here it refers to "regards croisés" between local planners in a certain place and time (Sao Paulo in the first decades of the 20th century), especially in relation to references read in Brazil that come from others countries. Case studies deeply analyzed can review the old approaches of a "comparative history" under new perspectives as the ones proposed by cultural transfers, connected, shared or crossed history. We know that in this case, we cannot think of a bi-lateral circulation that would permit to cross histories in a transnational dimension. About the limits of the word "circulation", theme just mentioned here, see Angotti-Salgueiro \& Simões (2017) (Article on line).
} 


\section{City planners of São Paulo and their transnational references}

São Paulo's astounding growth between 1870 and 1930 was a significant factor in introducing urban science into the remodeling proposals that emerged during that period. Over these sixty years, the city underwent strong economic and population increases, a result of the coffee production peak, intense immigration and later, industrialization. There were 24,000 inhabitants in the city in $1870 ; 240,000$ in 1900 , and a million thirty years later. A one thousand percent increase in the first period, and over four hundred percent in the second. The impact of this accelerated expansion process devoid of any urban planning left deep marks that have hindered city management to the present day.

Other factors favored the process of modernization that was impending from the nineteenth century. The main factor was the onset of the Republican regime in the country (1889), which organized the municipal public works sectors, and gave them greater autonomy. In the case of São Paulo, the creation of the Polytechnic School in 1894 provided training for civil engineers and engineer-architects to deal with urban management. These professionals joined the municipal public administration, contributing to the dissemination and application of many principles and paradigms from the science of city planning which was being developed in several countries.

In the first decade of the twentieth century, the big urban problems faced by the São Paulo's city government were divided into three types: sanitation, transportation (street network or road systems), and architectural esthetics. Engineers proposed plans and projects based on their professional practice referencing other contexts. These projects were supposed to regulate aspects such as the decongestion of the downtown area, installation of infrastructure systems (public health, lighting, electricity, gas, transportation, etc.), the esthetic and technical modernization of architectural heritage, street connections between the residential districts and downtown, control of urban sprawl, improving the conditions of houses in general and providing public housing and creating quality public spaces (urban furniture, green spaces).

Portuguese engineer Victor da Silva Freire stood out in this scenario, not only for his political role but also as the main proponent in obtaining international references for city planning. He was Director of Public Works for São Paulo for 26 years (1899-1925) and was a professor at the Polytechnic School of Engineering. Freire studied at the Polytechnic School in Lisbon and at the École des Ponts et Chaussées de Paris. Beginning in 1905, he frequently attended international city planning conferences ${ }^{5}$ and received the Proceedings of congresses held in Europe and the United States, appropriating these texts and attempting to apply them to the reality of the city of São Paulo.

The library of the Polytechnic School was another source for important document references, in special books, urban planning manuals, and specialized periodicals that were consulted by the generation of pioneer city planners ${ }^{6}$. While Victor Freire worked as Director of Public Works and a professor, he mentored the first São Paulo city planners, and some of them became his assistants in the city government. Worthy of note are engineers João Florence de Ulhoa Cintra, Arthur Saboya, Francisco Prestes Maia, and Luiz Ignacio Romeiro de Anhaia Mello, who could be considered, along with the

\footnotetext{
${ }^{5}$ According to Piccinato (1974) and Sutcliffe (1981) among the pre-World War I conferences that consolidated the international field of urbanism, most notable were Ersten Deutschen Städteausstellung, in Dresden (1903); Town Planning Conference (1910), that brought together in London the most renowned planners of the period, such as Rudolf Eberstadt, A. E. Brinckmann, Augustin Rey, Louis Bonnier, Thomas H. Mawson, Stanley D. Adshead, Joseph Stübben, Charles Mulford Robinson, Eugène Hénard, Patrick Geddes, Raymond Unwin, and Ebenezer Howard; then followed the Internationale Städtebau Ausstellung in Berlin (1910) and Dusseldorf (1913); and the Congrès International et Exposition Comparée des Villes, in Gand, also in 1913.

${ }^{6}$ The collection of the São Paulo Polytechnic School library includes some highlights such as: Town Planning in Practice by Raymond Unwin (1909); Études sur les transformations de Paris (1903-1909), by Eugène Hénard (1903); The Improvement of Towns and Cities and The Widht and Arrangement of Streets by Charles Mulford Robinson (1901); Civic Art by Thomas Mawson (1911); Der Städtebau (1924 - 3o ed.), by Joseph Stübben (1924); L'Art de bâtir les Villes by Camillo Sitte's (1902) (original 1889 in German); Garden Cities of Tomorrow, by Ebenezer Howard (1902), as well as various other books of planning pioneers: Nelson Lewis, Harland Bartholomew, John Nolen, and Augustin Rey.
} 
public health engineer Francisco Saturnino Rodrigues de Brito, born in Rio de Janeiro, the main pioneers of city planning in São Paulo.

The questions proposed by these pioneers discussed below are focused on the following aspects: improvements in downtown area, controlling urban sprawl, modeling the city's growth and diffusing the anti-metropolis ideas.

\section{Improvements in downtown area (1911)}

Victor da Silva Freire (1911) was behind some important projects for São Paulo, subscribing to Camillo Sitte's vision by maintaining the morphology of the historic central area. For the expansion areas, he preferred the British "garden-city" standard. He proposed a plan for downtown called "Os Melhoramentos de São Paulo" (Improvements for São Paulo), in 1911, to solve the urban congestion and the connections between the central area and the up-and-coming residential districts. This pioneering document is an example to analyze the transfers from international city planning ideas. The bibliographical references that Freire quoted were as follows from four works: Sitte's (1902) book L'Art de construire les villes, Eugène Hénard's (1903) Études sur les transformations de Paris, Charles Mulford Robinson's (1901) The Improvement of Towns and Cities or the Practical Basis of Civic Aesthetics, and Charles Buls' (1893) Esthétique des Villes.

In addition to these books, Victor Freire also used the plans and the specifications studied by French city planner Joseph-Antoine Bouvard during his intervention in the city of Buenos Aires in 1907. Bouvard was a consultant in São Paulo in 1911 and gave his opinion on the stalemate of the proposed projects. On validating Freire's plan (Figure 1), he proposed to expand it, and furthermore, he became associated with the City Company (City of São Paulo Improvements and Freehold Land Company Ltd.), resulting in the initiation of new ways for designing housing lots.

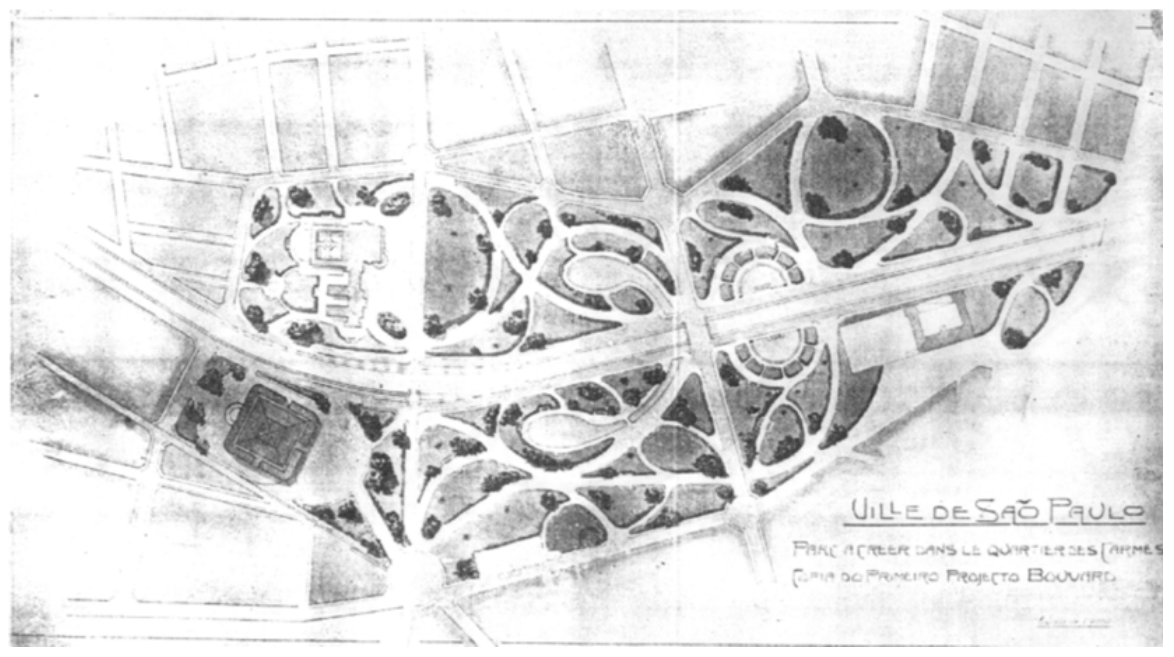

Figure 1 - Plan Bouvard, proposed for São Paulo, adopting Sitte's premises respecting the preservation of the historical center (1911). Source: Prefeitura Municipal de São Paulo (1912).

\section{Controlling the urban expansion areas (1913-1923)}

The rapid expansion of the urbanized area demanded a great amount of effort by the city government to control the approval process for new streets and neighborhoods. Until the 1920s, legislation was inappropriate for the site of the city, whose topography was very irregular, marked by valleys and slopes. The old rules of 1886 recommended that all streets should be straight and 16-meters wide. That would mean an orthogonal road grid for the whole city, which would be a solution for flat 
areas, but not for some areas of São Paulo. Beginning in 1910, Victor Freire conducted the revision of these regulations and was later supported by British urban planner Barry Parker, who lived in the city for two years to implement the new districts of a real-estate company, the above-mentioned City Company.

Freire's technical argument was also based on the ideas of German Joseph Stubben (Freire, 1915) and those of British city planner Raymond Unwin from the garden cities movement. It resulted in the approval of new modern street network regulations in 1923. Stübben's essay, "Practical and Aesthetic Principles for the Laying Out of Cities" had been presented in Chicago, at the Colombian Exhibition, in 1893, guiding principles for new street networks in expansion areas. In summary, it proposes a general conception of road design based on the radial-concentric model, i. e., a central nucleus and radial roads connecting it to the peripheral zones, thus defining different urban sectors. The sectors are subdivided by concentric or ring-shaped roads, and within each of these trapezoidal-shaped subsectors, local lanes would have an orthogonal outline and a diagonal street. The whole system was conceived for traffic flow efficiency.

The profile of the streets should promote drainage and resist large changes in the topography. Discrete curvatures are recommended along the street layout, avoiding the very long straight line. The width of the streets should always be designed according to the volume of traffic and circulation. Improvements will depend on a suitable width, good implementation of the construction on the lot, the existence of open spaces for squares and green areas along the roads and inside the lots. These principles presented by Stübben and then also recommended in Unwin's work (Town Planning in Practice) changed the city planning rules in São Paulo and permitted occupation of large steep areas with a proper road system, as well as providing savings in paving and drainage works. These principles were put into effect under the new street plan law, no. 2611 of 1923, to which the engineer Luiz de Anhaia Mello greatly contributed (Figure 2).

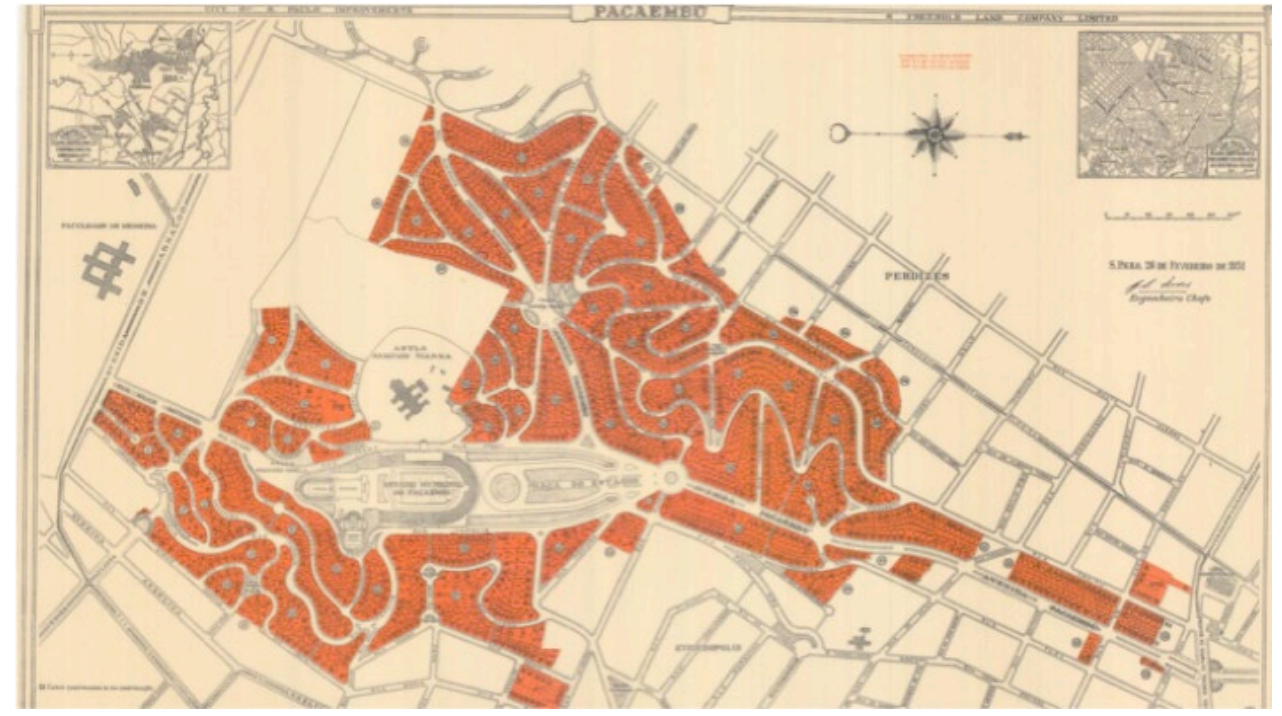

Figure 2 - Plan of urbanization for the district of Pacaembu, with reference to the ideas of the English garden-suburbs by Raymond Unwin, realized in São Paulo by City Company, and based on the modifications allowed by the law n²311 (1923). Source: Cia City de Desenvolvimento Urbano Archive.

\section{Adapting the city's growth to a new urban model (1922-1930)}

During the 1920s, other city planners stood out in the city: Francisco Prestes Maia, João Florence de Ulhoa Cintra and Luiz Ignacio Romeiro de Anhaia Mello, all of whom graduated from the Polytechnic School where they later became professors. Prestes Maia and Cintra worked together in municipal public works. Between 1922 and 1924, they published a study that would forever mark the city's future 
configuration. The study was based on the works of French city planner Eugène Hénard's (1903), Études sur les transformations de Paris, already mentioned. Prestes Maia and Cintra's study proposed that São Paulo should adopt the radial-concentric models, from the concept of "perimètre de rayonnement". Based on the idea that structuring the future metropolises would follow this pattern, according to the four schemes presented by Hénart for London, Paris, Moscow, and Berlin, Prestes Maia and Cintra developed the Plano de Avenidas (Plan of Avenues) for the city of São Paulo, projecting radial and perimetral avenues, including the two main rivers of the city in the model (Figure 3). The grand folio exposing this plan, illustrated with photos and watercolors, was published in 1930 and had a deep impact, given its graphic quality and a large number of references to German, British, North American, and French city planners. Nevertheless, this plan was only carried out during Prestes Maia's terms as mayor of the city (1938-45 and 1961-65), but not without criticism from a group of city planners who followed other lines of thinking, such as Luiz de Anhaia Mello.
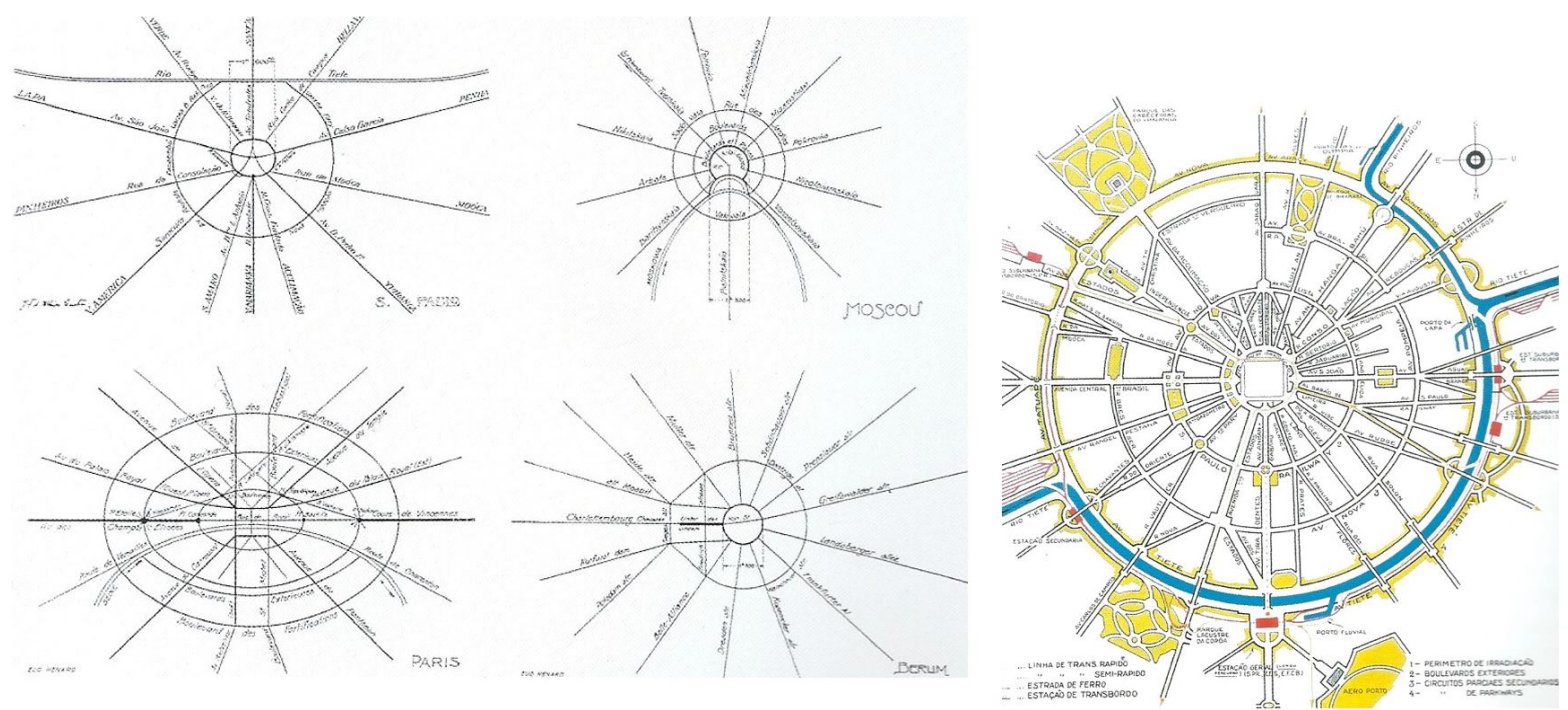

Figure 3 - Models of urban structure conceived by Hénard and the adaptation proposed by Prestes Maia for the Plan of Avenues of São Paulo 1930. Source: Maia (1930, p. 50-52).

\section{The anti-urban idea: a comprehensive and humanistic urban thought}

Engineer-architect Luiz de Anhaia Mello, professor of the Polytechnic School from the 1920s to the 1960s and a member of the intellectual elite of São Paulo, was the most important theorist in the field of urban planning in the city. He considered himself an "urbanist" throughout his career, with the "mission" of sensitizing "public opinion" and promoting education for town planning. In this sense, he defended the creation of civic associations according to the North American model, in which society would be part of urban improvements.

Around 1925, Anhaia Mello conceived a City Plan Commission, quoting models such as the Regional Planning Association of America (He owned all the volumes of the Regional Plan of New York and read Thomas Adams as well as others international authors on this subject). However, it was not until the 1950s that a master plan would only be widely discussed in São Paulo. In addition to being the executive director of the Engineering Institute, creating some controversies and briefly participating in city politics, Anhaia Mello founded the SAC-Sociedade de Amigos da Cidade (City Friends Society) in 1945. In his opinion, professional circles, councils, and planning committees had to be independent from the interference of the public government, which generated conflicts with his peers, who as we saw, had been proposing plans for the city following various lines of thought, since the 1910s. 
He created regular courses on City Planning ("Aesthetics, General Composition and Urbanism") at the Polytechnic School around 1926, and in 1948, he founded the School of Architecture and Urbanism at the University of São Paulo, to distinguish engineers from architects, and connect the latter with city planners and social scientists. Throughout his entire life, he was involved in disseminating the principles of an ideal city, under a humanistic and "civic urbanism", through an active and pedagogical series of public conferences (at the Rotary Club and the Engineers' Institute, for instance). His speeches and numerous articles were published in periodicals of professional associations, such as the Boletim do Instituto de Engenharia, among others, and in books, such as his first, Problemas de Urbanismo, in 1929. Some of his ideals are represented on "The Urbanism Tree" image published in this book: the roots are the propaganda or "public opinion", the trunk represents the "committees" and the tree canopy is "legislation" which resulted in the shade that represents "urban progress" (Figure 4).
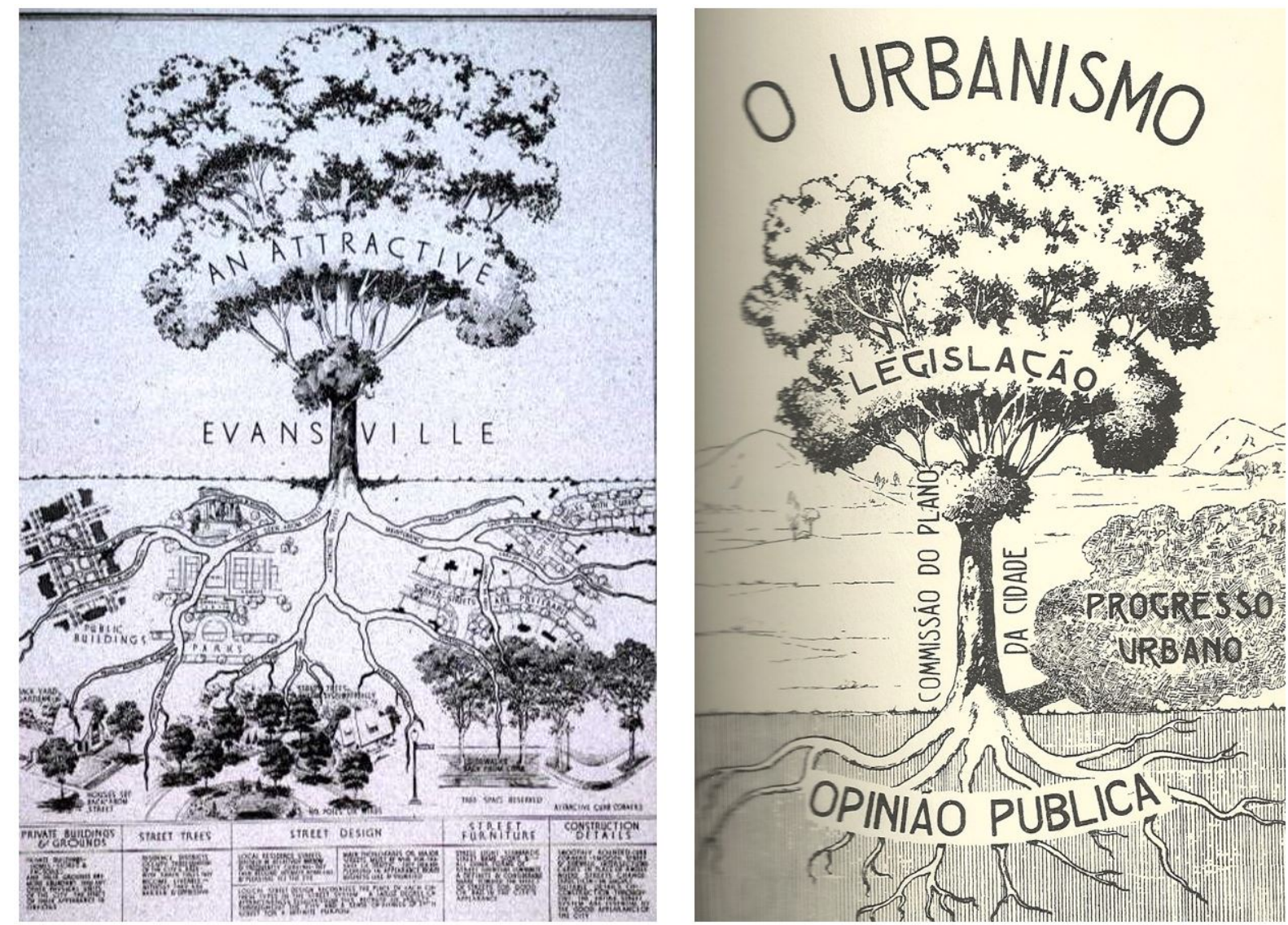

Figure 4 - "The Urbanism Tree" on the right is an appropriation made by Luiz de Anhaia Mello in 1929, who introduced notable changes in the original image of Harland Bartholomew's Evansville Plan dated 1927. Source: Bartholomew (1927) and Mello (1929).

In fact, Anhaia Mello disapproved of the then-current boastful slogan, which said: "São Paulo cannot stop". He was against skyscrapers and automobiles, and his main fight was to contain the growth of the tentacular city, introduce regional planning, and reaffirm statements by foreign authors. They ranged from the Belgian poet Emile Verhaeren (1895) to Patrick Geddes and his disciple Lewis Mumford, at the genesis of anti-urban critique, which culminated in reading Oswald Spengler on the decline of the machine civilization. 


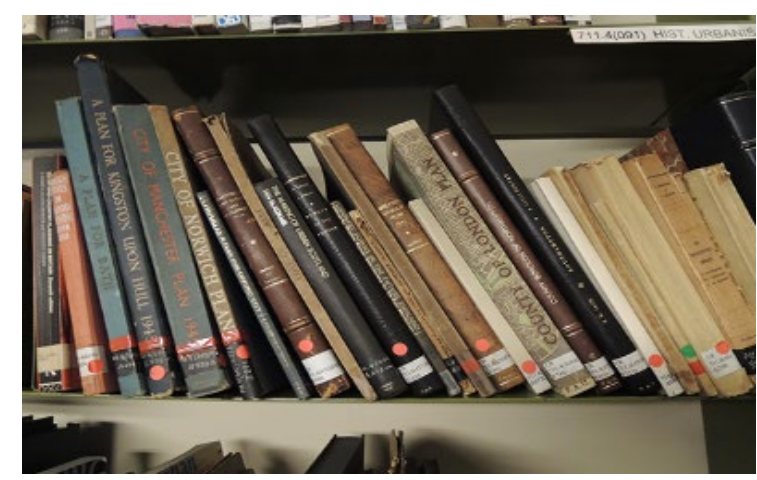

Figure 5 - View of some referential books of Anhaia Mello, in the library of Architectural School Department of Post-Graduation (FAU-USP), in São Paulo. Source: Archive of the author (Angotti-Salgueiro).

Anhaia Mello's personal library (Figure 5) is the main source of study of Angotti-Salgueiro's project ("Ideals and Readings of Luiz de Anhaia Mello - from 'urban art' to an humanistic city planning for Sao Paulo, 1930-1950") and is relevant evidence of his international knowledge and erudition, as he quoted many authors in his three books and in more than 70 articles he wrote. He left no personal archives, nor confidential autobiographical notes, so the research strategy was to study his texts and the marginal notes left in the more than one thousand books that belonged to him, and today are part of the library of the School of Architecture and Urbanism at USP. His library has classics of city planning history and its related fields. The books quoted in his articles demonstrate how he appropriated the authors he read, mainly North Americans, although he also quoted French authors even in his last texts in the 1960s ${ }^{7}$. This approach is part of a cultural history of reading practices, consistent with an intellectual biography, involving studies and institutional programs of that time ${ }^{8}$.

The circulation of journals and books in Sao Paulo was ensured among urban professionals through various channels, including the Boletim do Instituto de Engenharia, in which there was a session "Bibliography". In this session it was announced "the acquisition of books and subscriptions to magazines and technical publications" whose subscription could be made "through" the Institute; small calls informed the content of magazines that were "available to members and interested people", and the various magazines that arrived containing lists of references. In addition to the collections of the institutions, many professionals formed their personal libraries, and in the case of Anhaia Mello, the stickers in some books tell us that they were bought in the Triângulo Bookstore (in the old Thesouro street, in the center of São Paulo) and in Casa Garraux. It is said that Anhaia Mello never traveled abroad, and one of his articles informs in 1928 that he used to order books in New York, at The Baker and Taylor Company. Certainly, he would have corresponded with editors, a practice usual in his time, as well as with authors of international prominence in the areas he wrote about ${ }^{9}$.

Images from The City Plan of Memphis, Tennessee, by Harland Bartholomew, published in 1924, in Mello's library can be taken as guidelines to summarize the main directions of his reflections, which were also subjects of his courses at the Polytechnic School, supported by international references. These images are inscribed in the holistic view of a "comprehensive plan". The first example is Civic Art, which can evoke the aesthetics committees he wanted to create in order to control the "general composition" of the overall "urban architecture". This last expression can be attributed to Pierre Lavedan, whom Anhaia invoked when he recalled the need for an "esprit d'urbanisme" in the city, in addition to the remodeling and "beautification" defended by Victor Freire. The latter had already introduced the overall view where esthetics elements should be aggregated to the plans for sanitation and road system (Feldman, 2005). Another example is "Streets". Anhaia suggested laws about the

\footnotetext{
${ }^{7}$ See: Angotti-Salgueiro (2014) and notably about authors read by Anhaia Mello, see: Angotti-Salgueiro \& Simões (2016, 2017).

${ }^{8}$ Following the methodology of French authors of a cultural historiography: Roger Chartier, Jacques Revel, Jean-François Sirinnelli; and in the specific field of urbanism, see Viviane Claude (2006).

${ }^{9}$ For a detailed analyses on how references arrived in Sao Paulo, see H. Angotti-Salgueiro, “Luiz de Anhaia Mello's personal library crossing his texts, reference authors and images", non-published article.
} 
organization of the street network and its relation to the built spaces due to his beliefs that streets were dangerous places, citing traffic death statistics from American books and periodicals. Instead, he defended the green superquadras (superblocks), or the separation of pedestrians and cars. Another central example in his criticism coming from Bartholomew's book is "Transit". Anhaia Mello referred to the "chaos" caused by circulation of vehicles, writing articles on traffic control and traffic regulation, and did not forget improvement of mass transportation; in this sense, he is contrary to the "old circulatory urbanism" of Prestes Maia's Plano de Avenidas (Plan of Avenues) that would permanently mark São Paulo urban site.

Regarding the next example of Bartholomew's principles, "Public Recreation", Anhaia Mello defended a general system of parks with activities, or active and organized recreation in play-lots, playgrounds, playfields - then "rus in urbe", the city/nature connection by parkways. Multi-centered urban decentralization and health housing were also paramount topics for Anhaia Mello who organized the First Housing Congress in 1931 when he was São Paulo's mayor, also showing his interest in zoning policies. The denunciation of the blighted areas is inseparable from his criticism of urban density, or overcrowding. This is to be solved by the garden-cities, satellite towns, neighborhood unit cells - revealing in all these themes his readings of authors such as Ebenezer Howard, Raymond Unwin (in the French translation of Léon Jaussely, 1926), Frederick Law Olmsted, Jean Lebreton, John Nolen, F. J. Osborn, Lewis Mumford, James Dahir, Clarence Perry and Clarence Stein. The concept of public spaces connects to city planning and Anhaia Mello constantly refers to the quest for communitarian relationships among citizens, defended by the North American urban sociologists, such as Robert E. Park and Ernest Burgess. These readings confirm his persistent humanistic visions of an organic city and the basic functions of common well-being: inhabit, work, amuse body and soul, and circulate, going back to the principles of Athens' Charter.

Likewise, Anhaia Mello also reflects on the "Zoning", subject in several passages of Harland Bartholomew' (1924, p. 117) book and transcribes them in his 1929's book. In this matter, he is also a reader of Edward Basset and George B. Ford. He illustrates the topic in his book by translating the ironic image of a pamphlet in Evansville, Indiana: "Zoning Will Prevent This"10 (Figure 6). The zoning law Anhaia Mello proposed in the late 1930s and the master plan for São Paulo and its outskirts, although debated in the following years, would only materialize decades later. It would be far from the "new models of urban composition" and regional planning he wanted, as the city had not avoided disorderly growth and the extension of urban occupation, his major battles.

\footnotetext{
${ }^{10}$ The image about Zoning (whose source had not yet been accurately detected until Angotti-Salgueiro's recent research), reproduced in Anhaia Mello's (1929) book Problemas de Urbanismo, is a cartoon directly translated from the "educational campaign" made in the city of Evansville, Indiana (see Harland Bartholomew's Plans), by a cartoonist who was known in town, Karl Kae Knecht, working on the local newspaper Evansville Courier and Journal, from 1906 to 1960. This cartoon was also later published in City Planning 1, 1925, and in Karl B. Lohman's "classic," Principles of City Planning, in 1931, when he referred to educational campaigns on city planning and improvement - both readings were mentioned by Luiz de Anhaia Mello in his essays.
} 


\section{Zoning Will Prevent This}
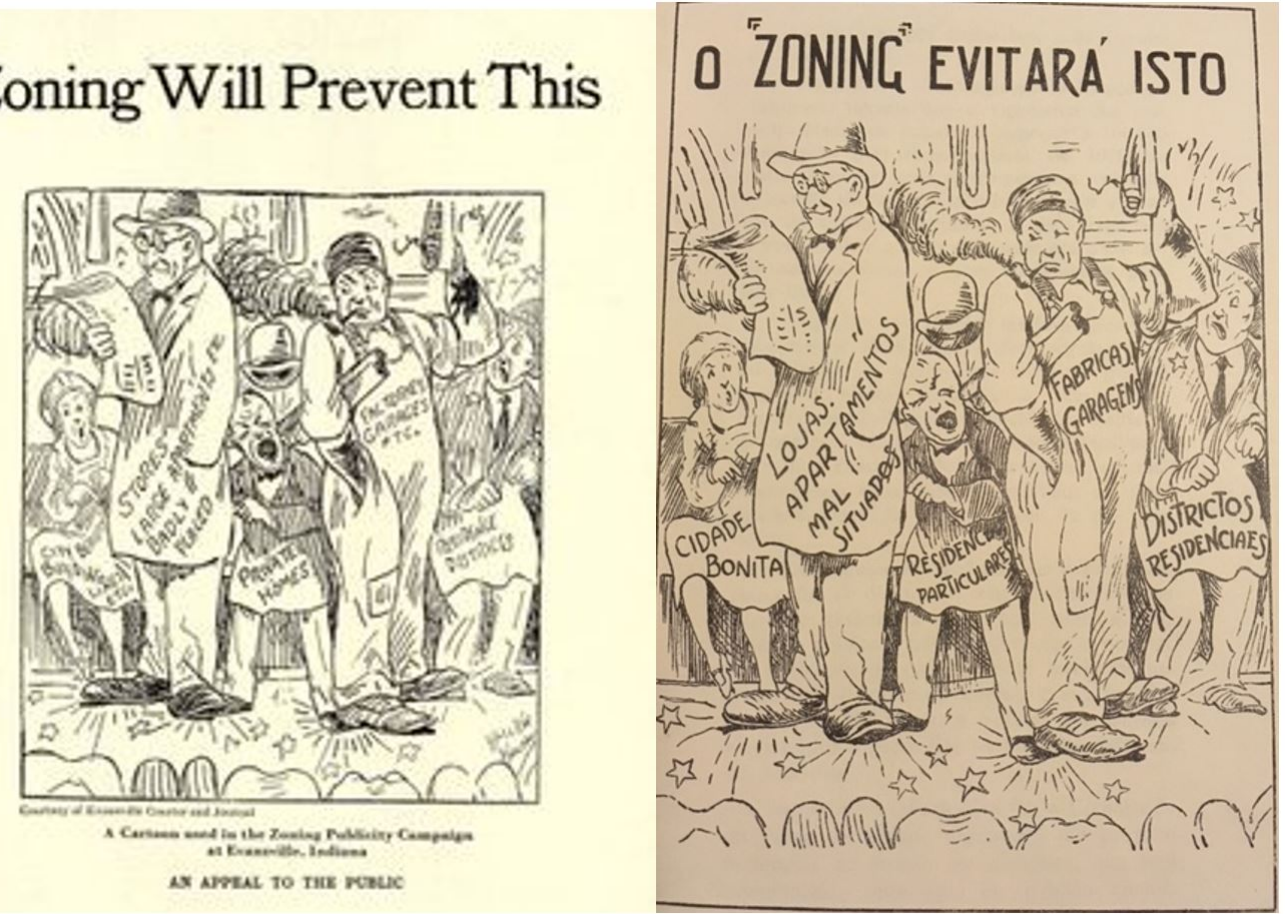

Figure 6 - A cartoon from a zoning campaign in Evansville, Indiana, before 1920, exactly translated to Portuguese by Anhaia Mello for his book Problemas de Urbanismo, in 1929. Source: Bartholomew (1924) and Mello (1929, p. 118).

\section{Conclusion}

Divergent urban models coexisted in São Paulo, where technical, academic and institutional circles debated the problems of the rapidly growing modernizing city, resulting from agro-export trade, immigration and then industrialization. In the first decades of the twentieth century, the projects of these polytechnical urbanists, pioneers in São Paulo, familiar with works of international origins, began to incorporate German, English and North American ideas. Meanwhile, some of their compatriots ${ }^{11}$ and urban-engineers in other Brazilian cities were still using Parisian references prioritizing straight avenues (percées), such as the previously done, Avenida Central, in Rio de Janeiro, that carried the symbolic weight of Haussmann's works in Paris. The abandonment of the traditional orthogonal and geometric layouts, characteristic of the conceptions of the nineteenth century, started to be questioned by Victor da Silva Freire, among others, who proposed new improvements paradigms for São Paulo beginning in 1911. We saw that these emerged not only due to the readings of Camillo Sitte's and Joseph Stübben's books but to British references that defended plans more adapted to the irregularities of the local topography, in addition to creating green spaces. These came through Raymond Unwin and the experience of the garden cities, soon adopted by real-estate companies such as City Improvements that profited from the growing demand for housing caused by meaningful urban expansion and population increase.

Starting in the 1920s, new actors came onto the stage and the circulation of foreign references grew with the dissemination of titles in the bibliographical sections of periodicals such as the Boletim do Instituto de Engenharia that mentioned several overseas publications, especially from the United States. In addition, there was the possibility of obtaining classic and recent works on city planning in local bookstores, as shown by the growing private libraries such as those of Luiz de Anhaia Mello and

\footnotetext{
11 The engineer Alexandre de Albuquerque and his plan for the "grand avenues" and a traffic circle like the Place de l'Étoile, constituted one of the many proposals debated in São Paulo during the 1910s. See Campos (2002) and Simões (2004).
} 
Francisco Prestes Maia, whose positions on the remodeling of the city were totally opposed. Prestes Maia and Ulhoa Cintra's Great Avenue's Plan prioritized circulation, practically ignoring principles of modern urbanism such as social and housing projects.

Luiz de Anhaia Mello, in turn, in his several published texts and courses at the Polytechnic School was aware of the times they were living in, i.e., the irreversible transformation of the city into a metropolis. He sought to regulate this progress, defending anti-urban ideas and a comprehensive plan against most of the engineers that were envisioning São Paulo with selective, partial and expansionist plans, limited to a street system, as is the case of Prestes Maia. Reason why Anhaia Mello was portrayed as a "dissident" (Arasawa, 2008) - we would say today a theoretical militant of the metropolitan "décroissance"12; his prediction about the capital's conurbation only worsened after the 1950s, to the detriment of an organic humanistic urbanity and the general regulatory planning he had idealized.

The engineers mentioned here who took part in the urban management, were responsible for the education of generations, although they left unfinished projects, speeches, acts, and their laws were partially applied; but on the other hand, they wrote a large number of articles and books. These are the sources, along with the private and institutional libraries they consulted, that are still waiting for new investigations, as for example editorial lines of periodicals, intersections between intellectual trajectories of local actors and foreign authors, and even appropriations of the same author to guarantee divergent ideas. Appropriations of transnational references may imply contradictions, partial coherence and limits of intelligible application of each country, demanding constant review and deeper research.

\section{Acknowledgements}

The authors are grateful for the funding obtained by Capes/PNPD and CNPq/Pq.

\section{References}

Almandoz, A. (2002). Planning Latin America's capital cities 1850-1950. London: Routledge.

Angotti-Salgueiro, H. (1997). La Casaque d'Arlequim: Belo Horizonte, une capitale éclectique au 19e siècle. Paris: EHESS.

Angotti-Salgueiro, H. (2014). Pensamento e leituras de Luiz de Anhaia Mello: das propostas de arte urbana ao planejamento de um urbanismo humanista. In Anais do III Enanparq: Arquitetura, Cidade e Projeto: Uma Construção Coletiva. São Paulo: ANPARQ. Retrieved in 2019, May 14, from http://www.anparq.org.br/dvd-enanparq3/iniciar.htm

Angotti-Salgueiro, H., \& Simões, J. G., Jr. (2016). Luiz de Anhaia Mello: em busca de um urbanismo humanizado: ideário e autores de referência. In Anais do XIV SHCU: Cidade, Arquitetura e Urbanismo: Visões e Revisões do Século XX. São Carlos: USP.

Angotti-Salgueiro, H., \& Simões, J. G., Jr. (2017). Por uma reflexão sobre pioneiros do urbanismo no Brasil e modalidades de apropriação de ideários internacionais: revisando terminologias e conceitos. Arquitextos: Vitruvius, 17.

Arasawa, C. H. (2008). Engenharia e poder: construtores da nova ordem em São Paulo 1890-1940. São Paulo: Alameda.

Bartholomew, H. (1924). The city plan of Memphis Tennessee: a comprehensive city plan. Memphis: City Plan Commission.

\footnotetext{
12 Expression from the title of a recent collection being published in France: Les Précurseurs de la Décroissance, particularly the book of Thierry Paquot (Mumford \& Paquot, 2015).
} 
Bartholomew, H. (1927). Evansville downtown appearance. Evansville: HB Associates.

Buls, C. (1893). Esthétique des Villes. Brussels: Bruyland-Christople.

Campos, C. M., No. (2002). Os Rumos da Cidade. Urbanismo e Modernização em São Paulo. São Paulo: Senac.

Claude, V. (2006). Faire la ville: les métiers de l'urbanisme au XXe siècle. Marseille: Parenthèses.

Espagne, M. (2013). La notion de transfert culturel. Revue Sciences/Lettres, (1). http://dx.doi.org/10.4000/rsl.219.

Feldman, S. (2005). Planejamento e zoneamento em São Paulo 1947-1972. São Paulo: Fapesp/Edusp.

Ficher, S. (2005). Os arquitetos da Poli: ensino e profissão em São Paulo. São Paulo: Edusp.

Freire. V. S. (1911). Os melhoramentos de São Paulo. Revista Polytechnica, (33), 91-146.

Freire. V.S. (1915). A capital Paulista - Presente e Futuro - a ação oficial - a ação particular. São Paulo: Almanach 0 Estado de São Paulo. pp. 175-195.).

Gomes, M. A. F. (2009). Urbanismo na América do Sul: circulação de ideias e configuração do campo 1920-1960. Salvador: EDUFBA.

Hénard, E. (1903). Études sur les transformations de Paris. Paris: Librairies-Imprimeries Réunies.

Howard, E. (1902). Garden cities of tomorrow. London: Swan.

Leme, M. C. (2005). Urbanismo no Brasil 1895-1995. Salvador: EDUFBA.

Maia, F. P. (1930). Estudo de um plano de avenidas para a cidade de São Paulo. São Paulo: Melhoramentos.

Mawson, T. H. (1911). Civic art. London: Batsford.

Mello, L. A. (1929). Problemas de urbanismo: bases para a resolução do problema technico. São Paulo: Escolas Profissionais Salesianas.

Mumford, L., \& Paquot, T. (2015). Lewis Mumford: pour une juste plénitude. Neuvy-en Champagne: Passager Clandestin.

Novick, A. (2003). Foreign hires: french experts and the urbanism of Buenos Aires, 1907-1932. In M. Vollait, \& J. Nasr (Eds.), Urbanism, imported or exported? Native aspirations and foreign plan. Chichester: Wiley Academy.

Pereira, M. C. S. (2003). Notas sobre o urbanismo no Brasil: construções e crises de um campo disciplinar. In Machado, D. P., Pereira, M. S., \& Silva, R. C. M. (Eds.), Urbanismo em questão. Rio de Janeiro: Prourb/FAU-UFRJ. Piccinato, G. (1974). La construzione dell úrbanistica: Germania 1871-1914. Roma: Officina Edizione.

Robinson, C. M. (1901). The improvement of towns and cities or the practical basis of civic aesthetics. New York: Putman's Sons.

São Paulo. Prefeitura Municipal. (1912). Relatório de 1911 apresentado à Câmara Municipal pelo prefeito Raimundo Duprat. São Paulo: Casa Vanorden.

Simões, J. G., Jr. (2004). Anhangabaú: história e urbanismo. São Paulo: Imprensa Oficial/Senac.

Sitte, C. (1902). L'art de batir les villes. Paris: Laurents. 1st ed., 1889 “Der Stadtebau nach seinen kunstlerischen Grundsatrzen, Wien".

Stübben, J. (1924). Der städtebau: handbuch der architektur. Leipzig: Gebhard. 1st ed., 1890.

Sutcliffe, A. (1981). Towards the planned city: German,Britain, the United States and France (1780-1914). New York: St Martin Press.

Unwin, R. (1909). Town planning in practice. London: Unwin.

Verhaeren, E. (1895). Les villes tentaculaires. Paris: Mercure de France. 
Werner, M., \& Zimmermann, B. (2004). Penser l'histoire croisée: entre empirie et réflexivité. In M. Werner, \& B. Zimmermann (Eds.), De la comparaison à l'histoire croisée. Paris: Seuil. First version published in Annales HSS, 581, 2003, and also in Portughese in the same year, in Textos de Historia, 11, 1-2, 2003.

Editor: Rodrigo Firmino

Received: May 14, 2019

Approved: Nov. 06, 2019 